THE INDUSTRIAL INSTITUTE FOR ECONOMIC AND SOCIAL RESEARCH

WORKING PAPER No. 460, 1996

SWEDEN'S RELATIVE

ECONOMIC PERFORMANCE:

LAGGING BEHIND OR STAYING ON TOP?

by Magnus HenREKSON 


\title{
Sweden's Relative Economic Performance: LAGGING BEHIND OR STAYING ON TOP?*
}

\author{
by
}

Magnus Henrekson

January 1996

JEL Classification: 01,047 and 050.

Keywords: Catching up, Economic growth, Swedish Economic Performance, Swedish Model.

Forthcoming in The Economic Journal.

Industrial Institute for Economic and Social Research, IUI

Box 5501

S-114 85 Stockholm

SWEDEN

\footnotetext{
* I am grateful for useful comments and suggestions from the participants at an IUI seminar. Financial support from the Swedish Council for Research in the Humanities and Social Sciences (HSFR) is gratefully acknowledged.
} 


\section{Introduction}

Sweden came out of the Second World War as a very rich country, relatively speaking. A high rate of growth was sustained throughout the 1950 s and 60s and by the end of the 60s Sweden was the richest country in Europe with the exception of Switzerland. This is no longer the case, which has stirred a lively debate among social scientists.

The debate in Sweden (mostly conducted in Swedish) has taken place at two different levels. On the one hand, there has been a lively discussion whether Swedish economic performance has been weak relative to other comparable countries. On the other hand, a second discussion has focused on whether this (possibly) weak performance can be explained by the fact that the economic structure of Sweden has deviated in key respects from that of other OECD countries.

The purpose of this paper is confined to illuminating the first of these two aspects: Has Swedish economic growth been slow relative to other industrialised countries in recent decades, i.e. is Sweden lagging behind?

In section 2 the Swedish growth record will be characterised in order to discover if and to what extent Sweden has been lagging behind in recent decades. In section 3 I will critically evaluate the assertion made by Walter Korpi in this issue of the Economic Journal that Swedish economic growth has, on the whole, been comparable to that of other countries. Section 4 concludes.

\section{The Swedish Growth Record}

In the middle of the nineteenth century Sweden was among the poorest countries in Europe. A take-off began in the 1850s, and in the early 1870s, industrialisation based on raw materials provided a base for sustained economic growth which continued largely uninterrupted for one hundred years. Swedish productivity growth was exceptional in the period 1870-1950 compared to other rich countries, and even when the period is extended to 1970, Sweden comes out as having the highest rate of labour productivity growth among the 16 countries compared by Maddison (1982). 
Sweden's growth rate in GDP per man-hour was very close to the average for the 16 countries in 1950-70. If we exclude the extremely war-torn countries Germany and Japan, which disproportionately benefited from a positive catching-up effect, the Swedish growth rate was somewhat above the average for the period 1950-70.1 A similar picture emerges from a comparison of growth rates for GDP, GDP per employed and GDP per capita for the 1950s and 1960s with averages for OECD and OECD Europe. ${ }^{2}$

Sweden's growth rate began to slow down relative to other countries around 1970. From Table 1 it is clear that the growth rate of GDP in Sweden has been only slightly more than half that of the OECD from 1970 to 1993.3 For GDP per capita the difference is slightly smaller, the Swedish growth rate is roughly 60 percent of the OECD rate. Sweden compares most favourably with the two aggreagates in terms of GDP per employed. However, this is entirely explained by the extreme fall in Swedish employment in the 1991-93 downturn. In order to facilitate comparability Mexico has been excluded throughout from the OECD aggregate. 4

\section{Table 1}

The slow economic growth rate in Sweden since 1970 has had a highly significant impact on the Swedish income level vis-à-vis that of other countries. Comparing income levels is known to be more difficult than comparing growth rates across countries. The most suitable method is probably to use the OECD's purchasing-power-parity adjusted measures of GDP per capita. Table 2 shows that Sweden had the 3rd (or 4th, see note of Table 2) highest GDP per capita in the OECD area in 1970, 9 per cent above the OECD average. In 1993 Sweden was ranked 17th with a GDP per capita 12 per cent below the OECD average.

Table 2

Figure 1

In order to obtain a more complete picture of Sweden's relative performance, it is worthwhile to study the entire time path of income relative to other countries rather than just compare two points in time. In Figure 1 (left scale) we can see that there is a clear downward trend in Swedish relative income even excluding the 1992-93 recession. At any rate, it should be noted here as well that 1989-90 were extreme boom years with 
unsustainable rates of unemployment at 1.4 and 1.5 per cent, respectively.

An important methodological point worth stressing is that consistency should be maintained between growth and level comparisons. More specifically, is the average growth rate for GDP per capita in Sweden of 1.14

per cent in 1970-93 when measured in national real prices (as in Table 1) consistent with the growth rate implied by the drop in the PPP-adjusted level of GDP per capita presented in Table 2? If indeed GDP per capita in OECD grew on average by 1.98 per cent from 1970 to 1993 and the Swedish average income dropped from 9 per cent above the OECD average in 1970 to 12 per cent below this average in 1993, it would imply that the Swedish PPPadjusted GDP per capita increased by 1.04 per cent p.a. during this 23-year period. Thus, it seems that a comparison of growth rates in national currencies is roughly consistent with the PPP-adjusted level comparisons at two points in time, although it should be noted that growth comparisons give a slightly more favourable view of the Swedish development. ${ }^{5}$ The reasons for this are unclear - unfavourable terms-of-trade effects may be part of the answer.

In summation, the analysis in this section shows that the rate of economic growth in Sweden was comparable to the average of other industrialised countries until the 1960s. But the data on growth and income levels clearly indicate that after 1970 Sweden's economic performance has been far below the average of other OECD countries. The accumulated effect of the slow economic growth has been substantial. In terms of PPP-adjusted GDP level per capita, Sweden now ranks in the lower half among the OECD countries. Thus, it appears quite clear that Sweden has been lagging behind other OECD countries in recent decades. And yet, Walter Korpi, in this issue and numerous other publications, argues vehemently that Sweden's growth performance has been comparable to that of other industrialised countries after 1970 as well. How can he draw this conclusion? In the following section I shall pinpoint and critically evaluate how Korpi is able to present such results.

\section{Salvaging the Non-Laggard Hypothesis}

Choosing different combinations of time periods; geawth measures, deflators and countries/aggregates to compare with, may convey 
substantially different impressions when one compares growth across countries. In this section I will attempt to uncover the choices that allowed Korpi to present Sweden as a non-laggard, despite the straightforward evidence to the contrary that I have presented above.

Korpi does concede that Swedish economic performance has been very weak after 1991. But he also claims that the "Sclerosis diagnosis" was firmly established in Sweden on the basis of OECD data ending in 1991, and that these data did not warrant the conclusion that Sweden was lagging behind. I will deal with this assertion specifically in several instances below.

\subsection{Choosing "propitious" time periods}

The relevant issue here is the rate of growth in Sweden relative to other countries in recent decades. Hence, the starting year for a growth comparison should be chosen against that background. 1970 is usually considered a watershed year in this respect. Korpi, on the other hand, chooses to use 1973 as his starting year, ${ }^{6}$ and he stops in 1989. Moreover, when he extends the data to 1990-91 these years are presented separately, because the development is seen as exceptional and thus should not influence the long-run averages. This proceedure is totally unwarranted: "the Sclerosis spokesmen" have claimed that Sweden has a long-run growth problem, and hence, as a purely statistical matter, the shorter the time period, the less forceful the critique against it. As Figure 1 illustrates, Korpi starts his comparison in a year when Sweden had a relatively deep recession (1973) and ends when Sweden had an extreme and unsustainable boom (1989).

If one does not like 1970 as a starting year, because it is a boom year, then it would be more appropriate to start a few years earlier, say in 1965 when the first signs of an underlying weakness in the Swedish economy appeared, rather than in 1973. By starting in 1965 we get the average growth of GDP and GDP per capita in Sweden, OECD and OECD Europe that are displayed in Table 3. As the reader can see, this extension of the period does not change the general picture. In the same table I also present growth rates for the periods 1965-91 and 1970-91 in order to counter Korpi's claim that no growth lag is apparent before the 1992-93 economic crisis. Even when we use 1991 as the cut-off point, the slow Swedish growth rate is apparent. Furthermore, as already shown in Table 2 above, by 1991 Swedish PPPadjusted GDP per capita had already fallen to 12th place (shared with Italy 
and Norway) among the OECD countries at a level 5 per cent below the OECD average.

Thus, this subsection shows that by focusing on the period 1973-89 in the comparisons Korpi has in effect excluded two periods of weak relative performance in Sweden (1970-73 and 1989-93), thereby giving an overly favourable impression of Swedish economic growth.

\section{Table 3}

\subsection{Ascribing long-term slow growth to mistakes in stabilisation policy} An implicit assumption underlying the alarm many display regarding Sweden's slow growth performance is that it is a symptom of underlying weaknesses in the economic, political and institutional system (see, e.g., Lindbeck et al., 1994). Korpi, on the other hand, claims that the lag in Sweden's GDP should primarily be ascribed to specific macropolicy mistakes, for example, too much fiscal restraint in 1970-71 and too much monetary restraint (disinflation) in 1990-91. Had these policy mistakes been avoided, the average long-run growth rate would have been much higher, and, consequently, the argument goes, it is quite legitimate to exclude the time periods when these policy mistakes lead to slow or negative growth!

This position is untenable. First, other countries have of course also made policy mistakes, and in order to be consistent these mistakes should also be excluded. Specifically, most European countries went through a period of tight monetary policy and disinflation at an earlier stage than Sweden; shouldn't we then exclude resulting years of slow growth in those countries as well? Second, it is perfectly possible that, due to the stabilisation policy pursued, the underlying weaknesses manifest themselves in recurrent crises rather than in a stable negative growth differential relative to other countries. In particular, if there is some leeway in the stabilisation policy to postpone necessary structural changes, recurrent crises appear to be the more likely manifestation of underlying structural weaknesses. In the Swedish case one could mention a series of devaluations in the 1976-82 period, a dramatic expansion of public employment in the 1970s and of transfers in the 1980s, and an unsustainable rate of credit expansion which fuelled the domestic economy in the 1980s.

A look at the data series is also sufficient to show that a macroeconomic 
recession is not followed by a number of years of above-normal growth leading to a return to the old underlying growth path. Instead the various crises have resulted in a permanent lowering of the GDP level. ${ }^{7}$ The same pattern may very well be repeated after the 1991-93 crisis as well (OECD, 1995).

\subsection{Appealing to the catching-up effect}

By appealing to the catching-up hypothesis, ${ }^{8}$ Korpi argues that growth comparisons should chiefly be made with the initially richest countries and not with all OECD countries. This is the justification given for the comparisons made with "six rich European countries". Even if we accept the catching-up argument it is hard to see, based on Table 2, why the U.S., Luxembourg and Canada are not included. Undeniably, there is plenty of evidence that a catching-up effect was operative in the 1950s and 60s, but there is also evidence that the catching-up effect is less relevant after 1970 (Abramovitz, 1986; Hansson and Henrekson, 1994). ${ }^{9}$ In this case, a comparison limited to the countries with the highest income in 1970 is misleading. At any rate, one should note that catching up concerns a closing of the gap to the leading country, whereas a change in the rank order of countries does not follow from the theory; notably, the theory cannot explain why one of the leading countries has ended up below the average. Thus, the Swedish drop in relative income from 3rd to 17th place after 1970 is not consistent with the catching-up theory.

There is some interesting evidence suggesting that, given the catching-up effect, Sweden performed remarkably well in the 50s and 60s, and that this was reversed in the 1970s. Dowrick and Nguyen (1989) estimated that Sweden's smaller scope for catching up led, ceteris paribus, to a lower rate of growth in GDP per capita during the period 1950-73 compared to the OECD average by approximately 0.8 percentage points. In the latter study, they also try to ascribe differences in growth rates across countries to contributions from increased labour force participation, increased capital deepening and growth in total factor productivity (TFP) after having controlled for the estimated catching-up effect. For Sweden they find that the rate of differential TFP-growth was strongly positive $(+0.79 \%$ p.a.) in $1950-60$, while it turned negative $(-0.25 \%$ p.a. $)$ in $1973-85$.

Furthermore, recent developments in endogenous growth theory (e.g. Romer, 1990, Grossman and Helpman, 1991, and Aghion and Howitt, 1992) 
also tell us that we should not necessarily expect slower economic growth in rich countries.

Overall, these considerations suggest that a fair evaluation of Sweden's relative growth performance cannot be confined to a comparison with a handful of initially rich countries. Lacking strong arguments to the contrary, the most reasonable comparison is with aggregates of countries as in Table 1 and 3 above.

\subsection{Levels in actual exchange rates rather than PPP-adjusted and absolute rather than relative growth}

When comparing GDP levels across countries it is crucial that the conversion makes sense. It is a well-known fact that the use of current exchange rates or exchange rates for an arbitrary year can be grossly misleading when GDP per capita levels are compared. To give the reader a sense of this problem, I compare the levels of GDP per capita in Sweden, Germany and the U.S. in 1993 at exchange rates for different years in Table 4. It is obvious that the use of current exchange rates gives rise to wide swings in GDP levels. The table also shows that it was not until the great depreciation of the Swedish krona after the conversion to a floating exchange rate system in 1992, which removed the earlier overvaluation of the krona, that comparisons using current rates and PPP rates began to give similar results. Thus, PPP-adjusted comparisons of GDP levels across countries are the only ones that give consistent and informative results.

\section{Table 4}

Based on his Figure 1 Korpi draws the conclusion that Sweden's "absolute advantage over the EEC and the other six rich countries tended to increase up to 1990". This conclusion is entirely due to the fact that the comparison is made using 1985 exchange rates. In 1985 the USD peaked and the EMS currencies were very low. The Swedish krona, on the other hand, was tied to a basket of currencies with a disproportionately large weight for the USD. In Figure 2 I have made the comparison with the "six rich European countries" using 1994 exchange rates instead. As we can see this reverses all the conclusions. The average income of the "six rich" is consistently above the level in Sweden and Sweden's absolute disadvantage tends to increase after 1975. This simple exercise just shows that nearly any proposition could be "proven" by picking exchange rates propitiously, and Korpi has chosen 
the exchange rate that verifies his proposition.

Figure 2

Therefore, even if the reader were to agree with Walter Korpi that it is reasonable to compare absolute rather than relative growth it is easy to show that absolute growth has been slower in Sweden than among comparable country groups. ${ }^{10}$ As shown in Table 2, in 1970 GDP per capita in Sweden was 9 per cent above the OECD average, 31 per cent above OECD Europe and 22 per cent above the EC level, while in 1991 Swedish GDP per capita had fallen to 5 per cent below the OECD average, 14 per cent above OECD Europe and 3 per cent above the EC level. It can be shown mathematically that as long as the average OECD growth rate was below 3.75 per cent p.a. the absolute growth in Sweden was lower than in all three country aggregates, and as we know from Table 3, the OECD growth rate was 2.11 per cent.

When Walter Korpi presents the development of GDP per capita in PPPterms he does it in a misleading way. In his Figure 2 he presents the development of PPP-adjusted GDP per capita in Sweden, OECD, EEC and the "six rich" European countries and comes to the conclusion that "the Swedish development quite closely follows that in the EEC as well as the average for the six rich European countries". Korpi presents nominal series, which very efficiently trick the eye of the reader. In Figure 1 I replicate and extend the Korpi curves for nominal PPP-adjusted GDP per capita for Sweden and the OECD (right scale). This is just a different mapping of the previously discussed PPP-adjusted GDP per capita relative to the OECD average, where the OECD average is normalised to 100 (left scale). As the reader can see, the two curves convey very different impressions. The nominal PPP-adjusted GDP seems to show a (roughly) unchanged difference between Sweden and the OECD from 1970 to the mid 1980s, but this implies a falling real difference - and, of course, a deterioration of the relative position (as shown explicitly by the relative income curve).

Finally, it is highly questionable in the first place to expect a lower relative growth rate in initially richer countries, and thus to focus on absolute growth in the comparisons. It presupposes mechanisms such as a strong catching-up effect, decreasing returns to scale or diminishing returns to capital. As already noted, it is unlikely that the catching-up effect is of much 
relevance any longer in explaining growth differences across countries at fairly similar income levels. Endogenous growth theory also tells us that using an extended measure of capital - including physical, human, social and knowledge capital - it is much less likely that there are decreasing returns. As argued by Romer (e.g. 1990), returns may even be increasing, since one component of the extended capital stock, namely knowledge, is nonrival. Romer (1989) also shows that if one takes a very long-run view (beginning in the 1830s) growth rates are increasing rather than decreasing over time, which stands in stark contrast to Korpi's presumption. In short, an evaluation of Sweden's relative growth performance is most appropriately conducted in terms of a comparison of relative growth rates.

\subsection{Making inferences about the whole economy from the performance of the (shrinking) manufacturing sector}

Between 1970 and 1993 the share of manufacturing in Swedish GDP fell from 26 to 18 per cent of GDP. Korpi makes the point that in the 1977-89 period labour productivity growth in Swedish manufacturing was on par with the average for ten other countries. From this finding he infers that "it is difficult to discover clear evidence for a long-term labour productivity lag in manufacturing of the type likely to have been caused by distorted market mechanisms". This conclusion merits at least two comments. First, 1977-89 constitutes only half the period of interest here; 11 if we consider a longer period Sweden is lagging also in this respect. For the 1970-91 period, labour productivity growth in Swedish manufacturing was 2.9 per cent p.a. compared to an average for the other countries of 3.6 per cent and 3.5 per cent when Japan is excluded. ${ }^{12}$ Second, what may appear statistically to be a rapid rate of productivity growth is likely to be largely the result of scrapping the least productive production units. Analogously, it may be noted that labour productivity growth has been extremely fast in the rapidly shrinking agricultural sector throughout the postwar period. ${ }^{13}$ In short, no conclusions regarding the performance of the aggregate economy can be made by referring to the rate of labour productivity growth in Swedish manufacturing in 1977-89. If anything, the long-run productivity performance in manufacturing gives further credence to the claim that Sweden has a growth problem.

\subsection{Large public sector said to give a negative bias}

Another factor claimed to bias the growth figures for Sweden downward is the large public sector, since productivity growth is by definition set to zero 
in the public sector. Of course there is a risk that the assumption of zero productivity growth in the public sector biases the Swedish growth figures downward. ${ }^{14}$ Nevertheless, there are at least two factors working in reverse, and Korpi mentions neither of them. First, the public sector share of GDP has increased since about 1970, which may in itself have contributed positively to registered GDP, because previously unregistered production such as elderly care and child care may have been shifted from households to the public sector faster than in other countries. ${ }^{15}$ Second, studies where one has actually attempted to measure public sector productivity show that, at least until the 1980s, an assumption of zero productivity growth in the public sector may have been too optimistic. One study of a large number of central government authorities found a productivity decrease of 2 per cent p.a. during the 1960-80 period..$^{16}$ In another study of the health sector a productivity decrease of 3 per cent p.a. was found for the same period. ${ }^{17}$

A downward bias is particularly unlikely when comparing the growth rate of GDP or GDP per capita during the period studied by Korpi.

\section{Concluding Remarks}

Relative to other rich countries, the rate of growth has been slow in Sweden for at least a quarter of a century. Perhaps the most striking result of this slow growth is that relative income in Sweden fell from 3rd or 4th to 17th place among the OECD countries from 1970 to 1993. Despite this evidence Walter Korpi has argued in numerous publications that those who claim that Sweden has been lagging behind have based their conclusions on "what with an understatement can be called careless analyses". Instead he asserts that Swedish growth performance has been on the whole in line with that of other comparable countries.

In this article I have tried to uncover how, against all odds, it is possible to give that impression. It is the result of a number of specific and unwarranted strategic choices regarding data selection and interpretations of the findings: Choosing propitious time periods, appealing to the catching-up effect in order to avoid comparisons with broad averages, focusing on absolute rather than relative growth in some cases and comparing levels by means of arbitrary exchange rate conversions instead of PPP rates, using nominal quantities in order to obscure the real development, interpreting 
weak long-run performance as the result of isolated policy errors while disregarding errors in other countries, and making unwarranted inferences about overall performance from the performance of subsectors of the economy.

Given that Sweden's key institutions and economic policy have deviated from many other OECD countries in recent decades, it is not surprising that many economists have argued that the slow economic growth may at least partly be explained by this deviation. Korpi dismisses the relevance of their arguments based on his assertion that Sweden has not, in fact, lagged behind. But since there is no convincing basis for Korpi's assertion, the reasons for Sweden's poor growth performance certainly merit close attention. However, this issue is too large to be dealt with in this paper.

Perhaps unwittingly, Walter Korpi shows in his article how important it is that social scientists, when necessary, reveal (or are aware of) their own underlying values. Korpi writes that "the Sclerosis spokesmen have presented a clearly biased selection of available evidence and data of relevance for their diagnosis". I hope that this article has convinced the reader that there is no basis for such an allegation; if anything, there may be a basis for the opposite allegation. 


\section{References}

Abramovitz, M. (1986) "Catching Up, Forging Ahead, and Falling Behind". Journal of Economic History 66, 385-406.

Aghion, P. and Howitt, P. (1992), "A Model of Growth Through Creative Destruction". Econometrica 60(2), 323-351.

Barro, R.J and Sala-i-Martin, X. (1995), Economic Growth. New York: McGraw-Hill.

Dowrick, S. and Nguyen, D.-T. (1989), “OECD Comparative Economic Growth 1950-85: Catching up and Convergence". American Economic Review 79(5), 1010-1030.

Grossman, G.M. and Helpman, E. (1991), Innovation and Growth in the Global Economy. Cambridge: MIT Press.

Hansson, P. and Henrekson, M (1994), "Catching Up in Industrialised Countries: A Disaggregated Study". Journal of International Trade and Economic Development 3(2), 129-146.

Henrekson, M. (1992), Sveriges tillväxtproblem. (Sweden's Growth Problem.) Stockholm: SNS Förlag.

Henrekson, M., Jonung, L. and Stymne, J. (1996) "Economic Growth and the Swedish Model". In Crafts, N.F.R. and Tonniolo, G., eds., Economic Growth in Post-1945 Europe. Cambridge: Cambridge University Press.

Korpi, W. (1996), "Eurosclerosis and the Sclerosis of Objectivity: On the Role of Values Among Policy Experts". Economic Journal, this issue.

Lindbeck, A. et al. (1994), Turning Sweden around. Cambridge, MA: MTT Press.

Maddison A. (1982), Phases of Capitalist Development. Oxford: Oxford University Press.

Mellander, E., Vredin, A. and Warne, A. (199?), "Stochastic Trends and Economic Fluctuations in a Small Open Economy". Journal of Applied Econometrics 7(4), 369394.

Nelson, C.R. and C.I. Plosser (1982), "Trends and Random Walks in Macroeconomic Time Series", Journal of Monetary Economics 10(2), 139 - 162.

OECD (1995), OECD Economic Suroeys - Sweden. Paris.

Produktivitetsdelegationen (1991), Drivkrafter för produktivitet och välstånd. (Incentives for Productivity and Welfare.) SOU 1991:82. Stockholm: Allmänna Förlaget.

Romer, P.M. (1989), "Capital Accumulation in the Theory of Long-Run Growth". In Barro, R.J., ed., Modern Business Cycle Theory. Oxford: Blackwell.

Romer, P.M. (1990), "Are Nonconvexities Important for Understanding Growth?". American Economic Review 80(2), 97-103.

Rosen, S. (1996), "Public Employment and the Welfare State in Sweden". In Freeman, R.B, Swedenborg, B. and Topel, R., eds., The Welfare State in Transition. Chicago: University of Chicago Press. 
${ }^{1}$ According to Maddison (1982, p. 212) growth in GDP per man hour in Sweden averaged 4.20 percent p.a. in 1950-70 as compared to an average of 4.46 percent for the average of all countries and 4.08 percent excluding Japan and Germany.

2 See Henrekson, Jonung and Stymne (1996) for details.

${ }^{3}$ The comparison ends in 1993 for the simple reason that this is the latest year for which complete data are available from the OECD. As far as we can see at this point a further extension forward would not change the comparison decisively to Sweden's advantage: In the latest issue of OECD Economic Outlook (June 1995) the average GDP growth rate is expected to be 2.4 percent in Sweden and 2.8 percent in OECD during the $1994-96$ period.

${ }^{4}$ This exclusion has been carried out by the Statistics Directorate of the OECD. Thus, indicated data sources have been used except for the aggregate OECD series, which were received directly from the OECD.

${ }^{5}$ The compounded effect of this differential of 0.1 percentage points p.a. is roughly percent on the GDP level in 1993.

${ }^{6}$ The reason for using 1973 as a dividing line in many growth comparisons is that the average long-run growth rates were lower after OPEC I. However, here we are not primarily interested in average growth rates across countries, but in the difference in growth rate between Sweden and other OECD countries.

${ }^{7}$ This is consistent with the main message from the so-called unit-roots literature, see,e.g. the seminal article by Nelson and Plosser (1982) and Mellander, Vredin and Warne (1992) for Sweden.

${ }^{8}$ The catching-up hypothesis maintains that when the productivity level is higher in one or more countries compared to a number of other countries, the latter have the opportunity to embark on a catching-up process by applying superior production techniques transferred from the more advanced economies. Hence, we should expect technologically less advanced countries to grow faster than the technologically leading country(ies). Korpi also claims that the "Sclerosis spokesmen appear to have been unaware of the catch-up/convergence hypothesis". Given the number of articles that have been devoted to this issue in the Swedish debate, this statement is no less than outrageous.

${ }^{9}$ This is also consistent with the finding of no absolute convergence in per capita income in a broader data set which includes developing countries, see, e.g. Barro and Sala-iMartin (1995).

${ }_{10}$ Parenthetically, it may be noted that Korpi erroneously maintains that I (Henrekson, 1992) have made comparisons in terms of absolute growth. What Korpi refers to was a calculation of the compounded effect on the GDP level of a certain growth rate differential, a perfectly legitimate exercise, which Korpi labels "an intellectual somersault".

${ }^{11}$ During this particular period Swedish manufacturing was boosted by no less than five devaluations.

12US Department of Labor, Bureau of Labor Statistics, August 1994. On the other hand, ironically and somewhat paradoxically, during the 1992-93 recession in Sweden, manufacturing labor productivity grew at almost 8 percent p.a., resulting in a Swedish labour productivity growth of just $0.1 \%$-points below the eleven country average for the period 1970-93.

${ }^{13}$ It should be remarked that Korpi uses data for Sweden from a different source than the other 11 countries, despite that data for Sweden are reported in that source. In the August 1994 data from the US Department of Labor, the productivity figures reported for Sweden are consistently slightly lower than the ones reported by Korpi.

${ }^{14}$ In some industrial countries a positive rate of productivity growth is assumed. However, Produktivitetsdelegationen (1991, pp. 115-117) shows that the effect on the Swedish rate of growth is almost negligible if one, as in Germany, were to assume an annual productivity growth rate of 0.5 percent.

15 It is also necessary that the increase is larger than the crowding out of private sector activity. In this context it may be mentioned that Rosen (1996) shows that all employment growth since 1963 is accounted for by increased female employment in the local government sector. A large part of these economic activities went unregistered before 1963. To the extent 
that this was the case, GDP was boosted.

${ }^{16}$ Statlig tjänsteproduktion. Produktivitetsutvecklingen 1960-1980. Report 1985:12 from Statskontoret, Stockholm.

17Produktions-, kostnads- och produktivitetsutoeckling inom offentligt bedriven hälso- och sjukodrd. Report to Expertgruppen för studier i offentlig ekonomi, Ds Fi 1985:3. Stockholm: Liber. 
Table 1 Average Annual Growth Rate of GDP, GDP per Employed and GDP per Capita 1970-93 (per cent).

\begin{tabular}{lrrr}
\hline & GDP & $\begin{array}{r}\text { GDP per } \\
\text { employed }\end{array}$ & $\begin{array}{r}\text { GDP per } \\
\text { capita }\end{array}$ \\
\hline Sweden & 1.49 & 1.37 & 1.14 \\
OECD & 2.76 & 1.73 & 1.98 \\
OECD Europe & 2.43 & 1.97 & 1.84 \\
\hline
\end{tabular}

Source: OECD National Accounts, Main Aggregates, Vol. 1, 1995, OECD Labor Force Statistics, 1995.

Table 2 PPP adjusted GDP per Capita in the 20 richest OECD Countries, EC and OECD Europe, 1970, 1991 and $1993($ OECD average $=100)$.

\begin{tabular}{|c|c|c|c|c|c|c|c|c|}
\hline \multicolumn{3}{|c|}{1970} & \multicolumn{3}{|c|}{1991} & \multicolumn{3}{|c|}{1993} \\
\hline \multicolumn{2}{|c|}{ Rank } & Index & $\operatorname{Ran}$ & & Index & Ranl & & Index \\
\hline & Switzerland & 146 & & U.S. & 125 & & Luxembourg $\dagger$ & $\dagger \quad 144$ \\
\hline 2 & U.S. & 140 & & Switzerland & 123 & & U.S. & 128 \\
\hline$\overline{3}$ & Sweden & 109 & & Luxembourg $\dagger$ & 118 & & Switzerland & 121 \\
\hline & Luxembourg $\dagger$ & 108 & & Germany & 111 & & Japan & 107 \\
\hline & Germany & 105 & & Canada & 109 & & Canada & 102 \\
\hline 6 & Canada & 10 & & Japan & 107 & & Belgium & 102 \\
\hline 7 & Denmark & 101 & 7 & France & 102 & 7 & Denmark & 101 \\
\hline 7 & France & 101 & 8 & Denmark & 99 & 8 & Austria & 101 \\
\hline 9 & Netherlands & 100 & 9 & Austria & 98 & 9 & Norway & 100 \\
\hline 10 & Australia & 99 & 9 & Iceland & 98 & 10 & France & 99 \\
\hline 11 & New Zealand & 97 & 11 & Belgium & 97 & 10 & Iceland & 99 \\
\hline 12 & U.K. & 93 & 12 & Italy & 95 & 12 & Germany $\ddagger$ & 97 \\
\hline 13 & Belgium & 90 & 12 & Sweden & 95 & 13 & Netherlands & 93 \\
\hline 14 & Austria & 87 & 12 & Norway & 95 & 14 & Italy & 92 \\
\hline 15 & Italy & 85 & 15 & Netherlands & 93 & 15 & Australia & 91 \\
\hline 16 & Finland & 81 & 16 & Australia & 91 & 16 & U.K. & 89 \\
\hline 17 & Japan & 80 & 17 & U.K. & 88 & 17 & Sweden & 88 \\
\hline 18 & Iceland & 75 & 18 & Finland & 87 & 18 & Finland & 82 \\
\hline 19 & Norway & 77 & 18 & New Zealand & 77 & 19 & New Zealand & 81 \\
\hline 20 & Spain & 63 & 20 & Spain & 92 & 20 & Ireland & 73 \\
\hline & EC 12 & 89 & & EC 12 & 92 & & EC 12 & 90 \\
\hline & OECD Europe & 83 & & OECD Europe & 83 & & OECD Europe & 81 \\
\hline
\end{tabular}

Note: Mexico is excluded from the OECD average. †Luxembourg revised its GDP estimate strongly upwards in 1995. According to the new figures Luxembourg had the highest GDP per capita also in 1991. Using the 1994 OECD publication Sweden was slightly ahead of Luxembourg in 1970, while using 1995 data Luxembourg per capita income was 16 percent higher than in Sweden in 1970. ‡The large drop in German income in 1993 is explained by the inclusion of eastern Germany. In order to get data for 1970 and 1991 excluding Mexico, the 1994 OECD publication was used for these years. Source: OECD Purchasing Power Parities and Real Expenditures. EKS Results Vol. 1, 1995 (for 1993) and OECD National Accounts, Main Aggregates, Vol. 1, 1994 (for 1970 and 1991). 
Table 3 Average Annual Growth Rate of GDP and GDP per Capita 196593, 1965-91 and 1970-91 (per cent).

\begin{tabular}{lrrr|rrr}
\hline & \multicolumn{3}{c|}{ GDP } & \multicolumn{3}{c}{ GDP per Capita } \\
& $1965-93$ & $1965-91$ & $1970-91$ & $1965-93$ & $1965-91$ & $1970-91$ \\
\hline Sweden & 1.96 & 2.27 & 1.83 & 1.52 & 1.84 & 1.50 \\
OECD & 3.13 & 3.27 & 2.89 & 2.30 & 2.43 & 2.11 \\
OECD Europe & 2.82 & 3.00 & 2.62 & 2.19 & 2.38 & 2.04 \\
\hline
\end{tabular}

Note: GDP is measured at the 1990 price level and exchange rates (USD).

Source: OECD National Accounts Main Aggregates Vol. 1, 1960-1993, 1995.

Table 4 GDP per Capita in Sweden, Germany and the U.S. in 1993 Using Different Exchange Rate Conversions (in USD).

\begin{tabular}{lrrrr}
\hline & 1985 rate & 1990 rate & 1993 rate & PPP rate \\
\hline Sweden & 19228 & 27949 & 21246 & 68 \\
Germany & 13221 & 24085 & 23546 & 83 \\
U.S. & 24302 & 24302 & 24302 & 100 \\
Sweden/Germany & 1.45 & 1.16 & 0.90 & 0.82 \\
Sweden/U.S. & 0.79 & 1.15 & 0.87 & 0.68 \\
\hline
\end{tabular}

Note: For the PPP comparison the U.S. is set equal to 100.

Source: OECD Main Economic Indicators, September 1994, OECD Economic Outlook, June 1995 (for exchange rates) and OECD National Accounts 1960-1993, 1995.

Figure 1 PPP Adjusted GDP per Capita in Sweden Relative to the OECD Average (left scale, OECD $=100$ ) and Nominal PPP Adjusted GDP per Capita in Sweden and the OECD (right scale), 1970-1993.

\section{Enclosed}

Source: OECD National Accounts, Main Aggregates, Vol. 1, 1994 (1970-92 for index series), OECD Purchasing Power Parities and Real Expenditures. EKS Results Vol. 1, 1995 (1993 for index series) and OECD National Accounts 1960-1993, 1995.

Figure 2 GDP per Capita 1960-93 in Sweden, EC and Six Rich European Countries (1990 prices and 1994 exchange rates).

\section{Enclosed}

Note: Six rich European countries are an unweighted average of Denmark, France, Germany, the Netherlands, Switzerland and the UK). The use of 1990 prices does not influence th level comparisons across countries in any systematic way, since it just determines the weights applied for the aggregation of GDP components within countries. Source: OECD Economic Outlook, June 1995 (for exchange rates) and OECD National Accounts 1960-1993, 1995. 


\section{Figure 1}

Relative income

Income at current PPPs

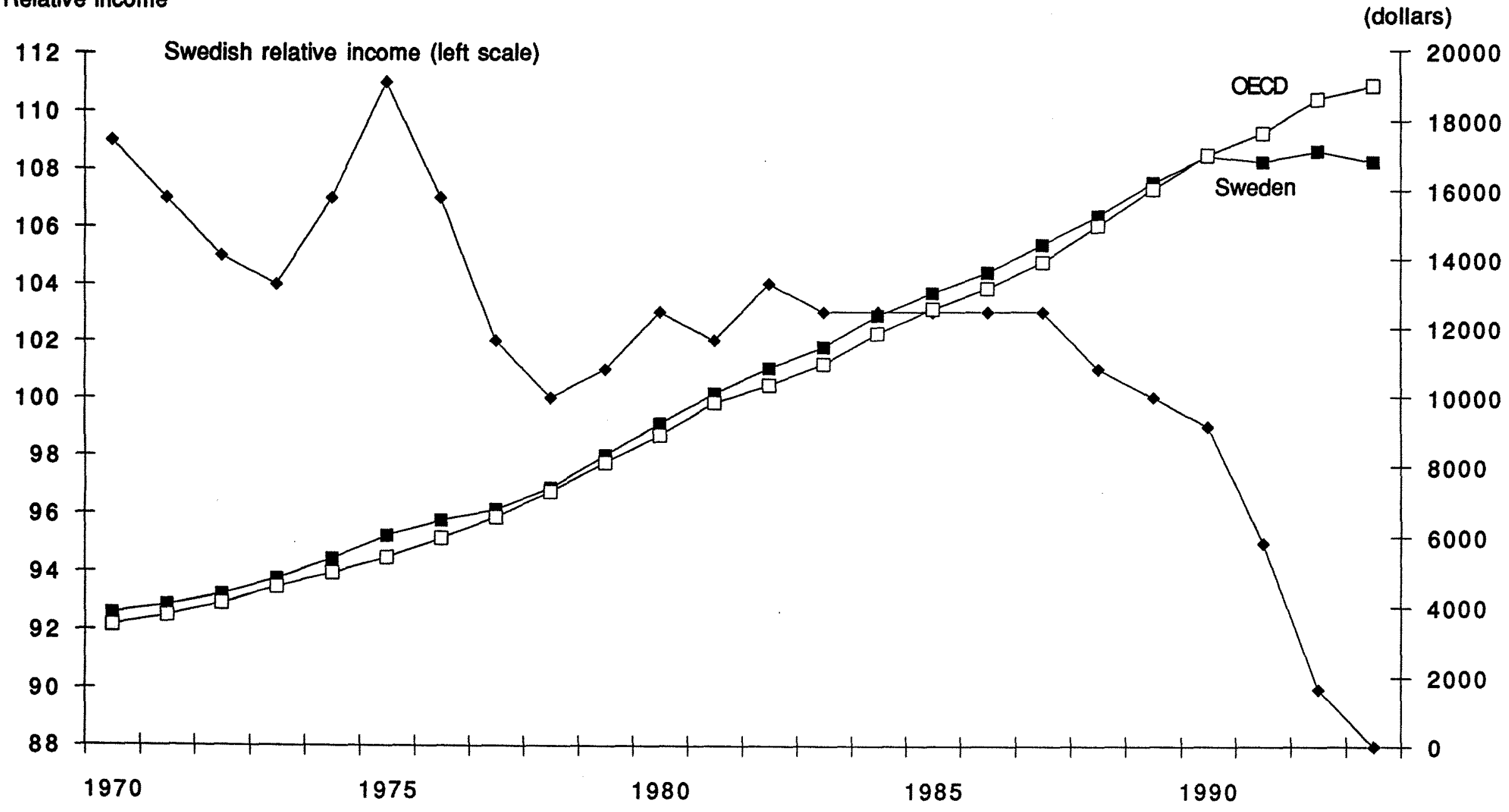


Figure 2

US dollars

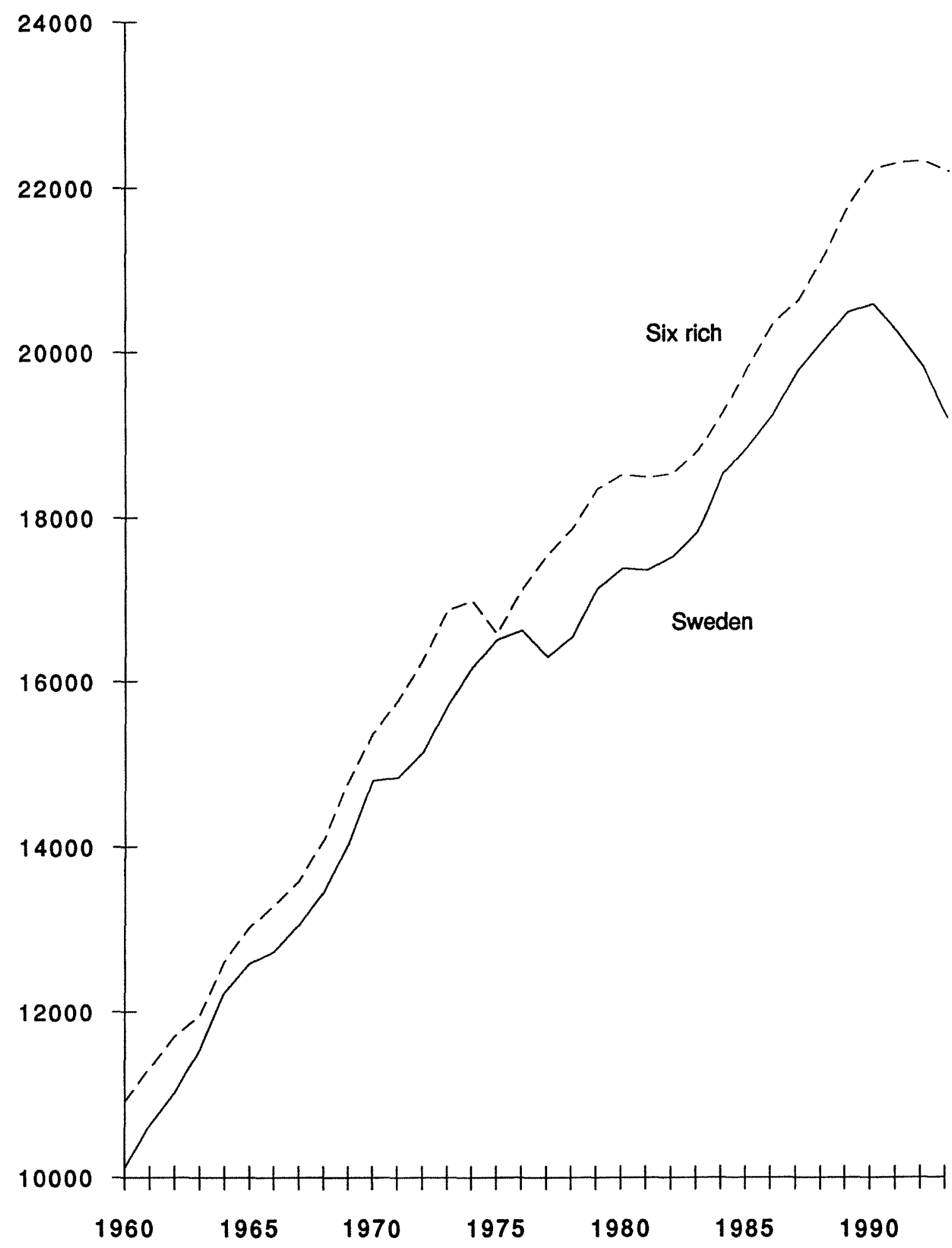

